\title{
Temperature responses of some North Atlantic Cladophora species (Chlorophyceae) in relation to their geographic distribution*
}

\author{
M. Cambridge, A. M. Breeman, R. van Oosterwijk \& \\ C. van den Hoek \\ Department of Marine Biology, Biological Centre, University of Groningen; \\ P.O. Box 14, NL-9750 AA Haren (Gn), The Netherlands
}

\begin{abstract}
The temperature responses for growth and survival have been experimentally tested for 6 species of the green algal genus Cladophora (Chlorophyceae; Cladophorales) (all isolated from Roscoff, Brittany, France, one also from Connecticut, USA), selected from 4 distribution groups, in order to determine which phase in the annual temperature regime might prevent the spread of a species beyond its present latitudinal range on the N. Atlantic coasts. For five species geographic limits could be specifically defined as due to a growth limit in the growing season or to a lethal limit in the adverse season. These species were: (1) $C$. coelothrix (Amphiatlantic tropical to warm temperate), with a northern boundary on the European coasts formed by a summer growth limit near the $12^{\circ} \mathrm{C}$ August isotherm. On the American coasts sea temperatures should allow its occurrence further north. (2) $C$, vagabunda (Amphiatlantic tropical to temperate), with a northern boundary formed by a summer growth limit near the $15^{\circ} \mathrm{C}$ August isotherm on both sides of the Atlantic. (3) C. dalmatica, as for C. vagabunda. (4) C. hutchinsiae (Mediterranean-Atlantic warm temperate), with a northern boundary formed by a summer growth limit near the $12^{\circ} \mathrm{C}$ August isotherm, and possibly also a winter lethal limit near the $6^{\circ} \mathrm{C}$ February isotherm; and a southern boundary formed by a southern lethal limit near the $26^{\circ} \mathrm{C}$ August isotherm. It is absent from the warm temperate American coast because its lethal limits, $5^{\circ}$ and $30^{\circ} \mathrm{C}$, are regularly reached there. (5) Preliminary data for $C$. rupestris (Amphiatlantic temperate), suggest the southeastern boundary on the African coast to be a summer lethal limit near the $26^{\circ} \mathrm{C}$ August isotherm; the southwestern boundary on the American coast lies on the $20^{\circ} \mathrm{C}$ August isotherm. For one species, C. albida, the experimental growth and survival range was wider than expected from its geographic distribution, and reasons to account for this are suggested.
\end{abstract}

\section{INTRODUCTION}

Van den Hoek (1982a) proposed that the geographic distribution boundaries of benthic algal species could be defined according to limiting temperatures, either for growth and reproduction in the favourable growing season or survival in the adverse season. This developed from the proposition of Hutchins (1947) regarding marine zoogeographic limits. The range of temperature at the boundaries of a species' geo-

\footnotetext{
- Paper presented at the Seaweed Biogeography Workshop of the International Working Group on Seaweed Biogeography, held from 3-7 April, 1984 at the Department of Marine Biology, University of Groningen (The Netherlands). Convenor: C. van den Hoek.
} 
graphic distribution would appear to be the best indication of its temperature limits in the natural environment. Thus, by examining summer and winter isotherms at boundaries, a range of temperatures can be inferred which the species must tolerate for it to occur at that boundary. These inferred temperatures may then be compared to experimentally determined limits to growth, reproduction and survival in order to suggest which part of the annual temperature regime is limiting the spread of a species beyond its boundaries. The boundary may be then defined specifically as due to a growth (or reproduction) limit in the growing season and/or a lethal limit in the adverse season.

Species of the genus Cladophora (Chlorophyceae, Cladophorales) have been selected for this study because, following taxonomic revisions of the genus (van den Hoek, 1963, 1979, 1982b; van den Hoek \& Womersley, 1984), they form a group of species whose systematics and geographic distributions are now reasonably well documented for large parts of the world's sea coasts.

This paper reports the results of experimental testing of six species of Cladophora belonging to four distribution groups, namely $C$. coelothrix belonging to the Amphiatlantic, tropical to warm temperate group; $C$. vagabunda and $C$. dalmatica to the Amphiatlantic, tropical to temperate group; $C$. rupestris and $C$. albida to the Amphiatlantic temperate group; and $C$. hutchinsiae to the Mediterranean-Atlantic warm temperate group.

\section{MATERIAL AND METHODS}

Isolates of 6 Cladophora species collected at Roscoff, France, and one isolate from Connecticut, USA (Table 1), were cultured in tubes with $10 \mathrm{mls}$ of Provasoli enriched seawater medium. Growth responses under constant temperature conditions ranging

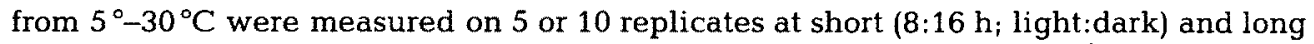
$(16: 8 \mathrm{~h})$ day conditions, photon flux density $40 \mu \mathrm{E} \mathrm{m}^{-2} \mathrm{~s}^{-1}$, using cloned material from tip cuttings, except for $C$. hutchinsiae for which sporelings were used. For general methods and equipment for cultivation, see Yarish et al. (1984).

Growth was measured as relative growth rate (RGR); after cutting from actively growing tips, fragments of approximately equal length were placed singly in tubes, and after a settling period of 3 days, drawn with a camera lucida and measured for length, or in the case of $C$. coelothrix, area, using a Hewlett Packard digitiser (Model 9835A). They

Table 1. Cladophora spp. isolates from Roscoff, France (May 1983), tested for temperature responses

\begin{tabular}{|c|c|c|}
\hline $\begin{array}{c}\text { Cladophora } \\
\text { spp. }\end{array}$ & $\begin{array}{l}\text { Isolate } \\
\text { code }\end{array}$ & Collection site \\
\hline \multirow[t]{2}{*}{ C. albida } & A 83.4 & Midlittoral tide pool \\
\hline & A 83.C. & Lagoon, shallow sublittoral \\
\hline C. coelothrix & C 83.14 & Muddy harbour, shaded low littoral rocks \\
\hline C. dalmatica & D 83.13 & Artificial pool, filling each day with tide \\
\hline C. hutchinsiae & H 83.8 & Exposed coast, shaded low littoral pool \\
\hline C. rupestris & R 83.9 & Exposed coast, deep shaded low littoral pool \\
\hline C. vagabunda & V 83.17 & Artificial pond, estuary, permanently filled with water, eutrophic \\
\hline
\end{tabular}


were then redrawn 3,7 and/or 10 days later for the subsequent length/area measurement(s), depending on the size of plants. Relative growth rate was calculated as

$$
\operatorname{RGR}=\ln \left(1_{2}-1_{1}\right) 100 / \mathrm{T}=\% \text { increment per day }
$$

where $l_{1}=$ initial length, $l_{2}=$ final length after $T$ days.

Survival was tested at $0{ }^{\circ} \mathrm{C}$ and $35^{\circ} \mathrm{C}$ and for some species $-5^{\circ} \mathrm{C}$. For $0{ }^{\circ} \mathrm{C}, 5$ tubes each containing a single plant were placed at light intensities of 10 and $20 \mu \mathrm{E} \mathrm{m}^{-2} \mathrm{~s}^{-1}$ at short day $(8: \overline{16} h)$ conditions. Plants were examined 2 months later for viability or signs of damage such as cell necrosis. In species where there was death and/or necrosis in some of the replicates, the plants were checked for their ability to recover by setting them at $20^{\circ} \mathrm{C}$ after increasing the temperature by $5^{\circ} \mathrm{C}$ intervals, each lasting 4 days. For $-5^{\circ} \mathrm{C}$, tubes with sporelings were set at progressively lower temperatures, being held at $5^{\circ} \mathrm{C}$ and then $0^{\circ} \mathrm{C}$ for 2 weeks each. The medium was then drained from the tubes, and they were wrapped in aluminium foil to exclude light and set in a freezer at $-5^{\circ} \mathrm{C}$. After 2 months, the plants were thawed for $24 \mathrm{~h}$ at $5^{\circ} \mathrm{C}$, still with light excluded. The tubes were then refilled with medium and after 2 weeks at $5^{\circ} \mathrm{C}$ placed at $15^{\circ} \mathrm{C}$ to test for active growth.

At $35^{\circ} \mathrm{C}, 5$ replicates of 1 plant per tube of $10 \mathrm{mls}$ PES were set at $35^{\circ} \mathrm{C}(16: \overline{8} \mathrm{~h})$ after progressively increasing the temperature by $5^{\circ} \mathrm{C}$ intervals, each lasting 4 days. Signs of damage were noted and mortality scored after 1-2 weeks, but the trial was continued for 2 months for those species tolerant of these high temperatures.

\section{RESULTS}

Generalised growth and survival characteristics of the seven species investigated are given in Figure 1. Species have been arranged according to the distribution groups distinguished by van den Hoek $(1979,1982 a, b)$. Figure 2 gives the temperature-growth curves for 6 strains (representing 5 species) for which growth rates are available over the temperature range of $5^{\circ}-30^{\circ} \mathrm{C}$ (or $\left.35^{\circ} \mathrm{C}\right)$.

In Figures 1 and 2, Cladophora coelothrix as a representative of the amphiatlantic tropical to warm temperate group, grew best at high temperatures $\left(25^{\circ}-35^{\circ} \mathrm{C}\right)$ but could not tolerate low $\left(0^{\circ}-5^{\circ} \mathrm{C}\right)$ temperatures, the actual lethal temperature depending on light period and light intensity, with increased tolerance to low temperatures in dim light and short days. Species in the amphiatlantic tropical to temperate group (C. vagabunda, $C$. dalmatica) were also able to grow best at high temperatures but survived low temperatures, at least lower than $0^{\circ} \mathrm{C}$. The amphiatlantic temperate species showed two forms of temperature response. The first, represented by $C$. rupestris showed growth at lower temperatures but no survival at high temperatures with the lethal temperature near $30^{\circ} \mathrm{C}$. The second form of response was exhibited by $C$. albida with good growth from medium $\left(15^{\circ} \mathrm{C}\right)$ to high $\left(30^{\circ} \mathrm{C}\right)$ temperatures and a very wide survival range beyond $-5^{\circ} \mathrm{C}$ and $35^{\circ} \mathrm{C}$. This response is similar to those of species with a tropical to temperate distribution. The species representing the warm temperate Mediterranean-Atlantic group (C. hutchinsiae) had a relatively narrow optimal growth $\left(15^{\circ}-25^{\circ} \mathrm{C}\right)$ and survival $\left(5^{\circ}-30^{\circ} \mathrm{C}\right)$ range and, as in the tropical to warm temperate species, the lower lethal temperature could be modified by light period and intensity. 

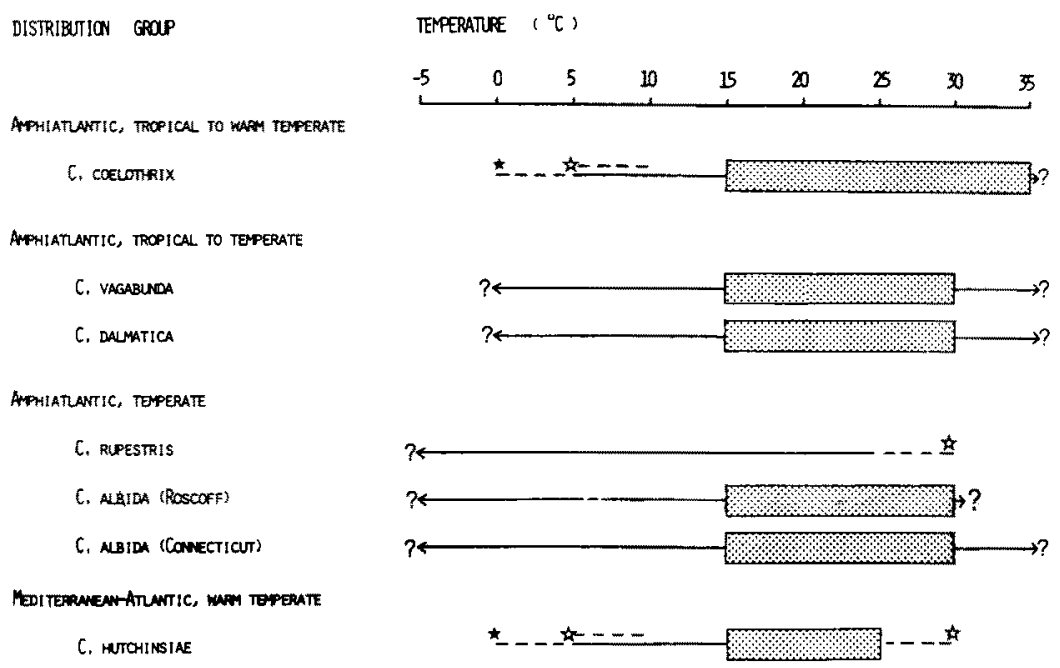

Fig. 1. Summary of experimentally determined temperature limits for growth and survival of selected Cladophora species, grouped according to distribution. Experiments at $5^{\circ} \mathrm{C}$ temperature intervals (as indicated on scale; Fig. 2). Shaded bar $=$ "good" growth in the interval, arbitrarily defined as $>20 \%$ of maximal growth rate (Fig. 2); solid line = survival in the temperature interval ${ }_{i}$ broken line $=$ temperature interval over which death of damage occurs; $5=$ plants dead or damaged in long days $(16: \overline{8} \mathrm{~h}) ; \star=$ plants dead or damaged in short days $(8: \overline{16} \mathrm{~h}) ;$ ? = survival beyond tested temperature range. For $C$. rupestris only survival has been tested at $-5^{\circ}, 25^{\circ}$ and $30^{\circ} \mathrm{C}$

\section{DISCUSSION}

Geographic patterns of distribution of six Cladophora species (Figs 3-8) and ocean isotherms at the northern and southern boundaries of distribution are compared here in order to test the validity of interpreting such patterns in terms of the temperature requirements for growth or survival.

\section{Cladophora coelothrix}

This species' optimum temperatures for growth $\left(25^{\circ}-35^{\circ} \mathrm{C}\right)$ shown in Figure 2 agree with its occurrence in the tropics. The high growth rate of $C$. coelothrix at $35^{\circ} \mathrm{C}$ probably reflects its occurrence in protected tropical lagoons where temperatures may rise considerably above $30^{\circ} \mathrm{C}$, as growth of even strictly tropical species tends to be depressed at $35^{\circ} \mathrm{C}$ (see McLachlan \& Bird, 1984). Its growth potential at $15^{\circ}-20^{\circ} \mathrm{C}$ (Fig. 2) permits its occurrence in the warm temperate Mediterranean Atlantic Region where these temperatures do occur in summer.

At the N.E. boundary (Europe) in Eire (Fig. 3), situated at the $8^{\circ} \mathrm{C}$ February isotherm and at the $14^{\circ} \mathrm{C}$ August isotherm, the species needs to survive winter temperatures of about $7^{\circ} \mathrm{C}$, which is above the experimentally determined lethal limit (between $0^{\circ}$ and $5^{\circ} \mathrm{C}$ ) indicating that this northern boundary is not a lethal one. In summer "sufficient" growth must occur at about $12^{\circ} \mathrm{C}$ (Fig. 3) and the experimentally determined limit for 


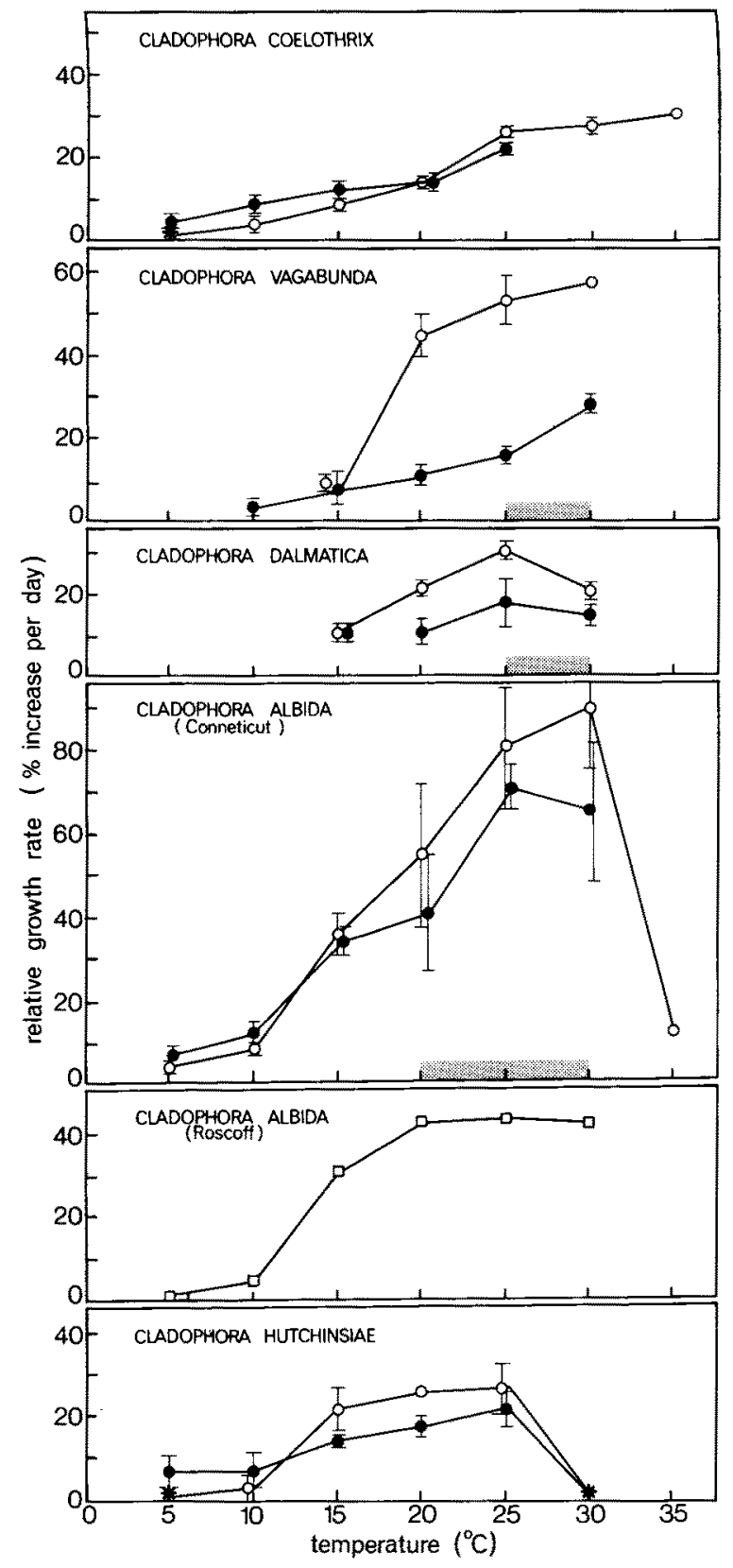

Fig. 2. Relative growth rates (RGR) of selected Cladophora species over the range of $5^{\circ}-30^{\circ} \mathrm{C}$ (vertical bar $=$ standard error of the mean). $O-O=$ long day $(16: \overline{8} \mathrm{~h}) . \bullet-\bullet=$ short day $(8: \overline{16} \mathrm{~h})$ conditions. RGR $=\%$ length increment $\cdot \mathrm{d}^{-1}$, for $C$. coelothrix, area increment. $\star=$ plants dead or damaged; shaded bar $=$ reproduction observed. All isolates from Roscoff, France except for a $C$. albida isolate from Connecticut, USA. $\square=C$. albida isolate from midlittoral tide pool at Roscoff 

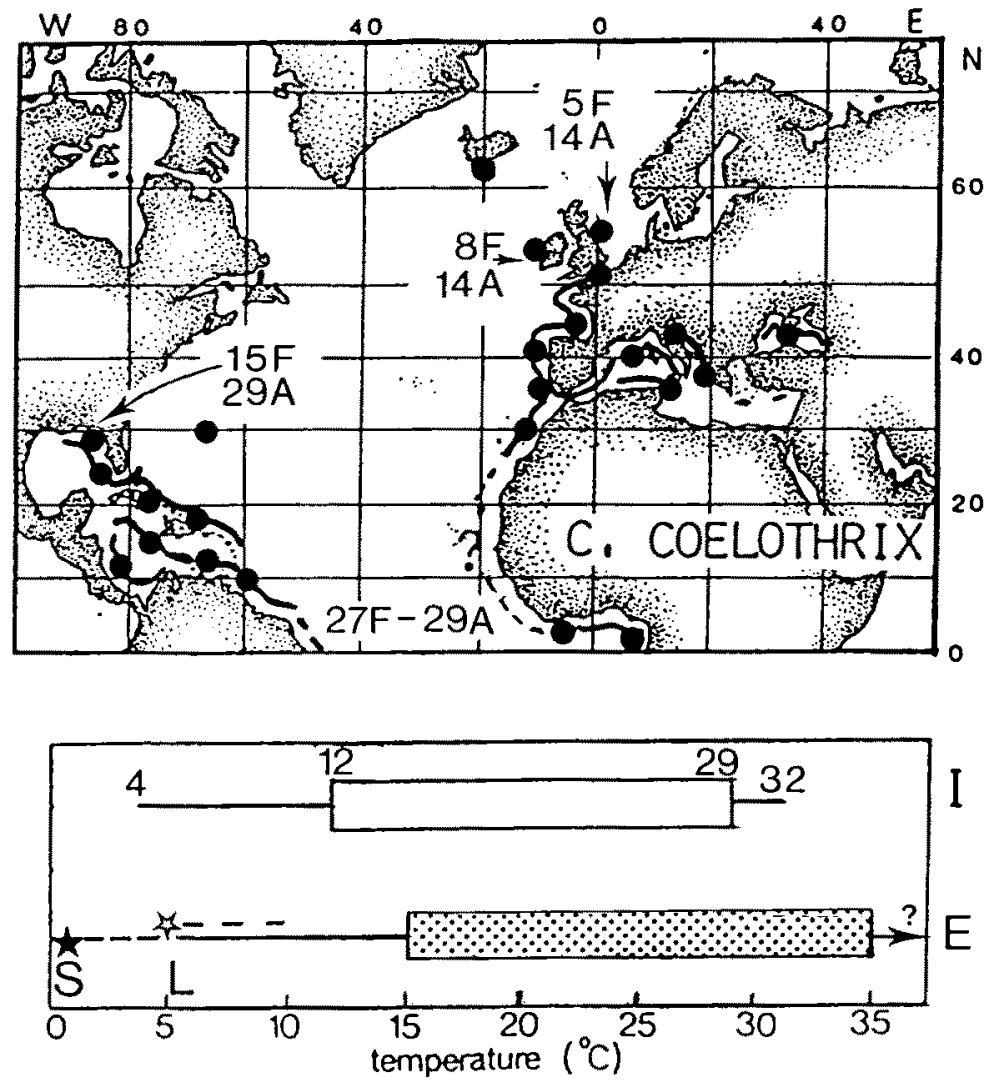

Fig. 3. Cladophora coelothrix (Amphiatlantic tropical to warm temperate distribution). Map shows geographic distribution on $\mathrm{N}$. Atlantic coasts, after van den Hoek (1963, 1982b). Continuous distribution shown as $\bullet-\bullet$, individual records as $(\bullet)$, here for Northumberland. February (F) and August (A) isotherms at boundaries and in tropics based on Sverdrup et al. (1942) and additional data summarised in van den Hoek (1982a). Bar diagrams compare thermal tolerance inferred (I) from distributional range with experimentally determined thermal limits ( $E$, for explanation of symbols see Fig. 1). Upper diagram (I) shows temperature ranges over which "sufficient" growth (open bar) and/or survival (single line) must occur to enable persistence throughout the distribution range, based on August (A) and February (F) isotherms at various northern boundaries and in tropics. Inferred thermal ranges determined as follows: lowest temperature at which species must be able to survive derived from lowest $F$ isotherm at any of the $\mathrm{N}$ boundaries modified, as in van den Hoek (1982a, p. 37), to account for survival in winters colder than average (thus Northumberland: $5^{\circ} \mathrm{C}$ Feb. $-1^{\circ} \mathrm{C}=4^{\circ} \mathrm{C}$ ), lowest temperature which must support "sufficient" growth derived from lowest $\mathrm{A}$ isotherm at any of the $\mathrm{N}$ boundaries modified, as in van den Hoek (1982a, p. 37), to account for "sufficient" growth in summers colder than average (thus Eire: $14^{\circ} \mathrm{C} \mathrm{Aug.}-2{ }^{\circ} \mathrm{C}=12^{\circ} \mathrm{C}$ ). Highest temperatures which must be survived in summer and must allow "sufficient" growth in winter derived from tropical $A$ and $F$ isotherms, respectively, modified, as in van den Hoek (1982a, p. 37), to account for years warmer than average (thus: $29^{\circ} \mathrm{C}$ Aug. $+3{ }^{\circ} \mathrm{C}=32^{\circ} \mathrm{C}$ in August, $27^{\circ} \mathrm{C}$ Feb. $+2{ }^{\circ} \mathrm{C}=29^{\circ} \mathrm{C}$ in Februaryl 
"sufficient growth" (here arbitrarily defined as $20 \%$ of the maximal growth rate) lies between $10^{\circ}$ and $15^{\circ} \mathrm{C}$ (Fig. 3). Therefore this boundary is best explained as a northern growth boundary (and not as a lethal boundary near the $8^{\circ} \mathrm{C}$ winter isotherm as suggested by van den Hoek, 1979, 1982a). The outlying record from Northumberland, based on a collection from 1902, is on the $14^{\circ} \mathrm{C}$ August isotherm as in Eire (Fig. 3) but also on the $5^{\circ} \mathrm{C}$ February isotherm. Here plants would have to survive $4^{\circ} \mathrm{C}$ in winter and since the experimentally determined lethal limit lies between $0^{\circ}$ and $5^{\circ} \mathrm{C}$ a winter lethal boundary may operate here in combination with a summer growth boundary.

The northwestern boundary (America) occurs in the Gulf of Mexico $15^{\circ} \mathrm{C} \mathrm{February,}$ $29^{\circ} \mathrm{C}$ August; Fig. 3) where C. coelothrix must survive at least $13^{\circ} \mathrm{C}$ in winter. This is far above the experimental lethal limit (between $0^{\circ}$ and $5^{\circ} \mathrm{C}$ ). It must also be able to grow "sufficiently" at least at $27^{\circ} \mathrm{C}$ in summer and again "sufficient" growth occurred at much lower temperatures (Fig. 3). Thus neither winter nor summer temperatures appear to be limiting the northward spread of $C$. coelothrix either further into the Gulf of Mexico or northward along the Florida coast. The answer may be in the unusual temperature regime of the eastern coast of North America. Inshore lagoonal waters reach winter temperatures as low as $0^{\circ} \mathrm{C}$ or less far to the south, and even in the Sounds of N. Carolina $\left(\sim 35^{\circ} \mathrm{N}\right)$ water temperatures drop to $0^{\circ} \mathrm{C}$ in winter (Searles, 1984). It is therefore likely that intermittent low lethal temperatures $\left(\sim 0^{\circ} \mathrm{C}\right)$ prevent $C$. coelothrix from occurring far to the north along the warm temperate coasts of N.E. America in the lagoonal habitats where this species usually occurs. However, one would expect $C$. coelothrix to occur more to the north than its present N.E. American northernmost record in southern Florida (van den Hoek, 1982b). We think that the scanty phycological exploration of the coasts between N. Carolina and S. Florida, combined with the notorious taxonomic difficulties in the genus Cladophora, are responsible for the lack of records, at least in the southernmost parts of these coasts. Thus, the northern boundary of C. coelothrix in the W. Atlantic Ocean is probably a lethal boundary. In that case, $C$. coelothrix has a northern composite boundary in the N. Atlantic Ocean: a lethal boundary in the W. Atlantic, and a growth boundary in the E. Atlantic. Experimental evidence points to the existence of comparable composite northern boundaries for other species in the tropical to warm temperate distribution-group: Dictyota dichotoma, Polysiphonia ferulacea (van den Hoek, 1982c), and Centroceras clavulatum (van den Hoek, 1982a).

\section{Cladophora vagabunda}

This species' optimal temperatures for growth $\left(15^{\circ}-30^{\circ} \mathrm{C}\right.$ ) (Figs 2,4$)$ and its survival range beyond $0^{\circ} \mathrm{C}$ and $35^{\circ} \mathrm{C}$ are in accordance with its wide distribution from temperate to tropical regions.

On its northeastern boundary (Fig. 4) in the Baltic Sea $\left(2^{\circ} \mathrm{C}\right.$ February, $15^{\circ} \mathrm{C}$ August), C. vagabunda must survive at least $1^{\circ} \mathrm{C}$ in winter but temperatures down to $0^{\circ} \mathrm{C}$ could be survived, thereby indicating that low winter temperatures do not set the northern boundary. However summer temperatures $\left(13^{\circ} \mathrm{C}\right)$ are within the interval where the growth rate falls below $20 \%$ of the maximum (between $10^{\circ}-15^{\circ} \mathrm{C}$ ) and so a summer growth limit is indicated on the $15^{\circ} \mathrm{C}$ August isotherm.

On the northwestern boundary in the Gulf of St Lawrence (Fig. $4,-1^{\circ} \mathrm{C}$ February, $15^{\circ} \mathrm{C}$ August), C. vagabunda would have to survive at least $-2{ }^{\circ} \mathrm{C}$ in winter on the open 

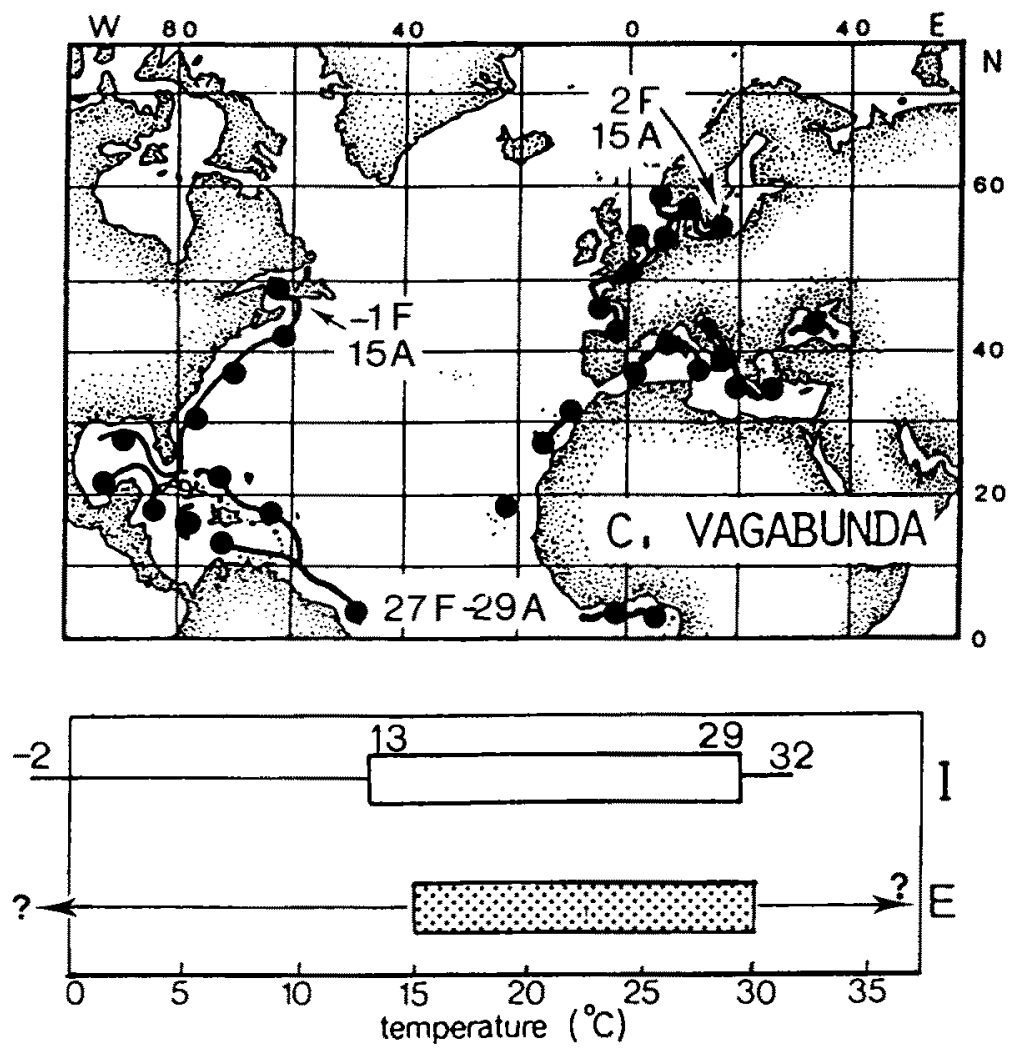

Fig. 4. Cladophora vagabunda (Amphiatlantic tropical to temperate distribution). See text to Fig. 3 for explanation of symbols

coast and must survive freezing in the enclosed bays and shallow lagoons where it occurs. Survival has not yet been tested below $0^{\circ} \mathrm{C}$, so it is not known if this is near a lethal temperature. The identical August isotherms (for open ocean water) at the northern boundaries in America and in Europe (both at $15^{\circ} \mathrm{C}$ Aug.) would indicate a northern growth boundary for the American coast as well. However, in the Gulf of St Lawrence, summer temperatures may rise as high as $25^{\circ} \mathrm{C}$ in shallow inshore lagoons (McLachlan \& Bird, 1984). Possibly the absence of such enclosed bays and shallow lagoons prevents the extension of $C$. vagabunda further north, so that the $15^{\circ} \mathrm{C}$ August isotherm on the open coast would effectively form the boundary.

In conclusion, the northern boundary of $C$. vagabunda can best be interpreted as a summer growth boundary near the $15^{\circ} \mathrm{C}$ August isotherm on both sides of the North Atlantic, as suggested by van den Hoek (1979), despite the higher summer temperatures in lagoons and bays on the N. American boundary. 

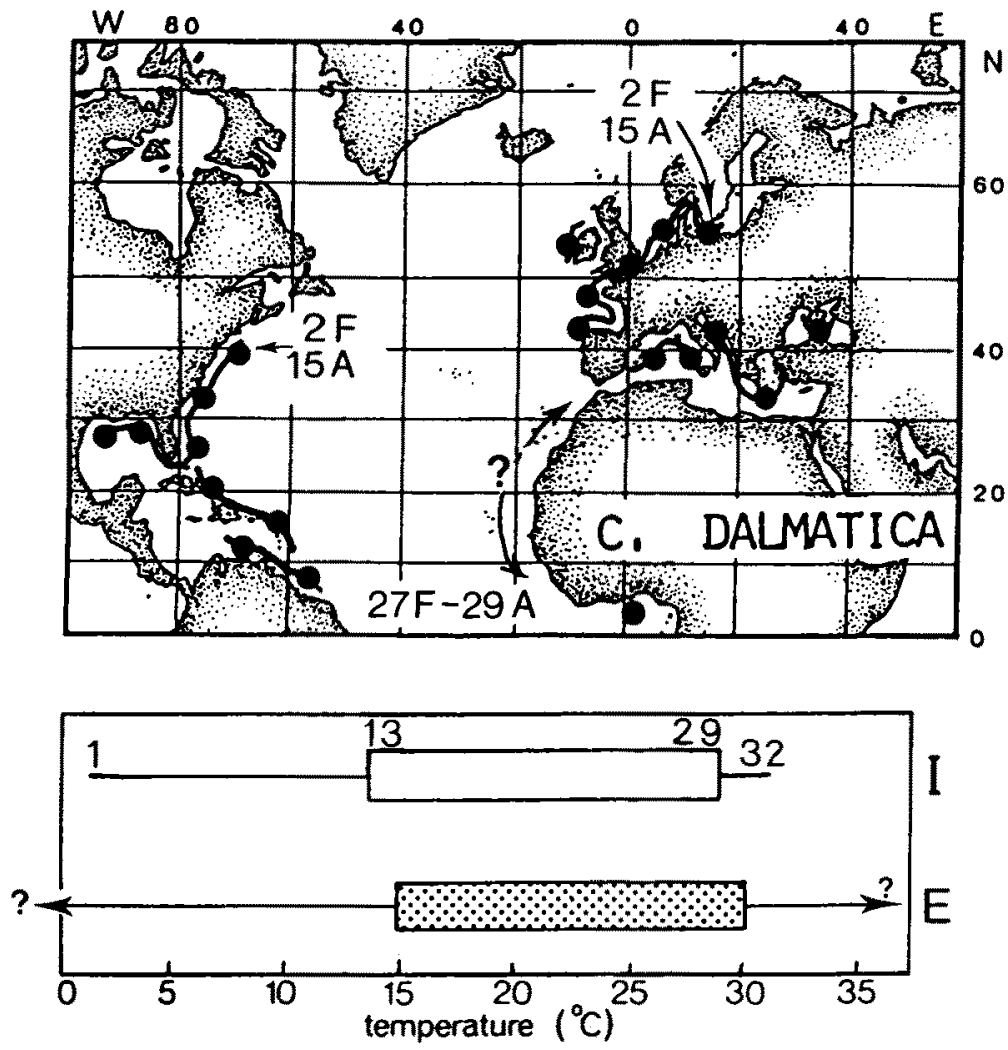

Fig. 5. Cladophora dalmatica (Amphiatlantic tropical to temperate distribution). See text to Fig. 3 for explanation of symbols

\section{Cladophora dalmatica}

As for $C$. vagabunda, this species' wide temperature ranges for growth and survival (Figs 2, 5) are reflected in its wide geographic range from tropical to temperate regions, although its northern extension is slightly more restricted. Growth at high temperatures $\left(25^{\circ}-30^{\circ} \mathrm{C}\right)$ is consistent with distribution through the tropics, although the maximum was measured at $25^{\circ} \mathrm{C}$, a little lower than that of $C$. vagabunda at $30^{\circ} \mathrm{C}$.

The northeastern boundary in the Baltic Sea on the $2{ }^{\circ} \mathrm{C}$ February and $15^{\circ} \mathrm{C}$ August isotherms (Fig. 5) again appears to be a summer growth boundary, as for C. vagabunda, since temperatures lower than the winter temperatures at the boundary were still survived (i.e. $0^{\circ} \mathrm{C}$ ) (Fig. 4).

On the northwestern boundary near Boston, the $15^{\circ} \mathrm{C}$ August isotherm passes down the coast from Newfoundland to Cape Cod, so that the boundary isotherm for $C$. dalmatica is the same as for the more northerly occurring $C$. vagabunda. As for the European coast a summer growth limit near the $15^{\circ} \mathrm{C}$ August isotherm would apply for the American coast. 


\section{Cladophora rupestris}

This species' upper lethal temperature between $25^{\circ}$ and $30^{\circ} \mathrm{C}$ and survival beyond $-5^{\circ} \mathrm{C}$ is consistent with its absence from the tropics and extension into cold temperate regions.

At its northern boundaries on both sides of the Atlantic (Fig. 6), winter temperatures are above $-5^{\circ} \mathrm{C}$, which is the lowest temperature so far tested which was still survived.
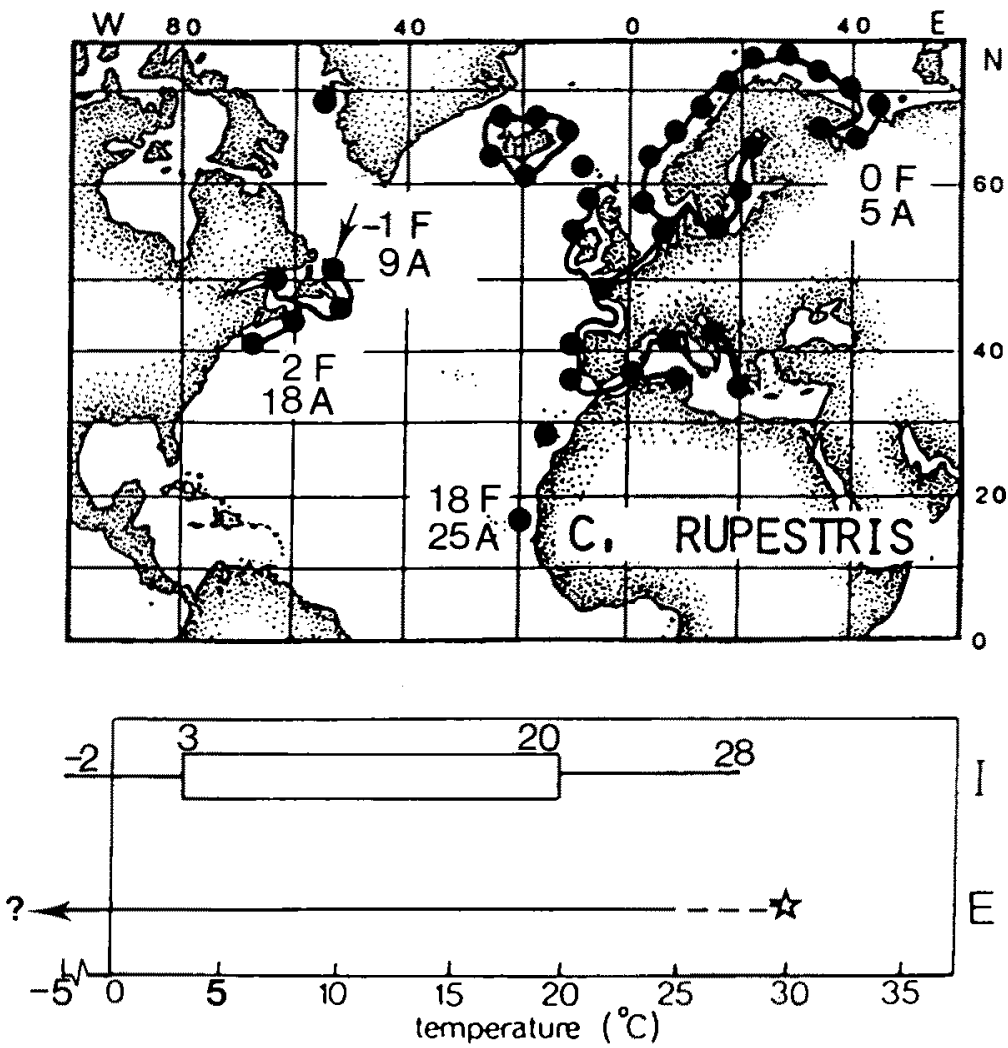

Fig. 6. Cladophora rupestris (Amphiatlantic temperate distribution). Additional distribution data for Newfoundland from South \& Hooper (1980), for Atlantic Morocco from Gayral (1958), for Senegal from Hamel (1924); Sourie (1954), partly as C. ramosissima (Drap. ex Kütz.) Kütz. See Fig. 3 for explanation of symbols. Equatorward, southern (S) boundaries are present so highest temperatures which must be survived and which must allow "sufficient" growth derived from highest values for A and $F$ isotherms, respectively, found at any of the $S$ boundaries. Values inferred as in Fig. 3 for tolerance required in tropics

Thus, the northern boundaries are not set by winter lethal sea temperatures. Perhaps they are set by growth limits but that cannot be substantiated at present without growth data.

On the southeastern boundaries on the African coast $\left(18^{\circ} \mathrm{C}\right.$ February, $25^{\circ} \mathrm{C}$ August), and in the Mediterranean $\left(16^{\circ} \mathrm{C}\right.$ February, $25^{\circ} \mathrm{C}$ August), C. rupestris would have to survive at least $28^{\circ} \mathrm{C}$ in summer, and since the experimentally determined lethal limit 

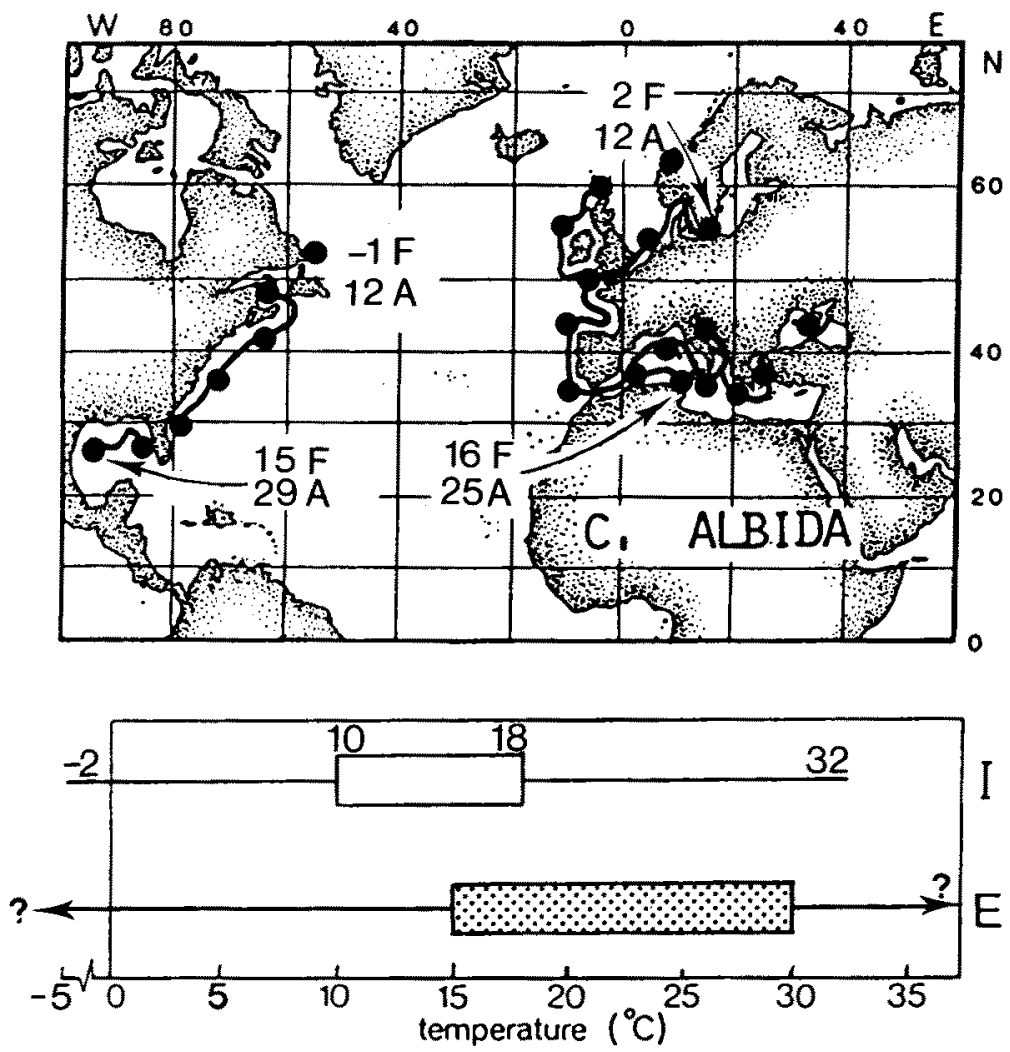

Fig. 7. Cladophora albida (Amphiatlantic temperate distribution). Additional distribution data for Norway from Rueness (1977). For Newfoundland from van den Hoek, unpublished: Bonne Bay, Aug. 1982, upper sublittoral. See text to Fig. 3 for explanation of symbols, equatorward southern boundary present

lies between $25^{\circ}$ and $30^{\circ} \mathrm{C}$, a summer lethal boundary seems likely here, on the $25^{\circ} \mathrm{C}$ August isotherm.

On the southwestern boundary at Long Island Sound, USA $\left(2{ }^{\circ} \mathrm{C}\right.$ February, $20^{\circ} \mathrm{C}$ August), summer open ocean temperatures are below the upper lethal temperature, so that high summer temperatures would appear not to limit the species distribution further south. There is no growth data but the $2^{\circ} \mathrm{C}$ February isotherm would indicate temperatures being low enough for growth in some seasons. However, on the coast further south, hard substrates are rare, until areas are reached where summer temperatures approach the upper lethal one. For example, on the coast of Delaware (Orris \& Taylor, 1973) and Virginia (Humm, 1979), summer surface temperatures regularly exceed $25^{\circ} \mathrm{C}$, as they do in the inner parts of Long Island Sound (Yarish et al., 1984) which would explain the species absence there.

In conclusion, the southern boundary of $C$. rupestris on both sides of the Atlantic is best interpreted as a southern lethal boundary as hypothesized by van den Hoek (1979, 1982a). 


\section{Cladophora albida}

This species optimal growth temperatures $\left(15^{\circ}-30^{\circ} \mathrm{C}\right)$ and survival beyond $35^{\circ} \mathrm{C}$ (Figs 1, 2) were unexpected in view of its absence from the tropics (Fig. 7). The temperature limits to growth are very distinct; between $10^{\circ}$ and $15^{\circ} \mathrm{C}$ there is a fourfold increase in growth rate and between $30^{\circ}$ and $35^{\circ} \mathrm{C}$ as much as a ninefold decrease (Fig. 2).

On the northern boundaries on both sides of the Atlantic, in Scotland and Newfoundland (Fig. 7), winter temperatures exceed the lowest temperature survived (tested to $-5^{\circ} \mathrm{C}$ ), but summer temperatures of about $10^{\circ} \mathrm{C}$ coincide with the lower limit for "sufficient" growth. Thus the northern boundary is a northern growth limit (represented by the $12^{\circ} \mathrm{C}$ August isotherm) as hypothesized by van den Hoek $(1979,1982 \mathrm{a}, \mathrm{b})$.

On the southern boundaries at Morocco and in the Mediterranean $\left(16^{\circ} \mathrm{C}\right.$ February, $25^{\circ} \mathrm{C}$ August) and the Gulf of Mexico $\left(15^{\circ} \mathrm{C}\right.$ February, $29^{\circ} \mathrm{C}$ August), winter temperatures are well below the upper limit for "sufficient" growth, and summer temperatures are less than the upper survival limit, which was above $35^{\circ} \mathrm{C}$. Thus, C. albida could be expected to occur through the tropics.

Two explanations are suggested; either the southern boundary is not due to temperature limits alone, but for example, to an imbalance of nutrient demand and growth rate at high temperatures in oligotrophic tropical waters, or the species occurs throughout the tropics and has not been recorded because of its rarity or because of problems in identification. For example, there is one old record of a typical C. albida plant from the "W. Indies" (the type of C. scitula (Suhr) Kütz. 1830, see van den Hoek, 1982b, p. 40), which may point to this species' occurrence in tropical E. America. In this area, C. albida can be easily confused with several narrowly related species (van den Hoek, 1982b). With regard to the tropical E. Atlantic coast, there is no critical revision of Cladophora available for most of the W. African tropical coasts, only a limited number of observations in van den Hoek (1982b), and literature records of this species or its synonyms are hardly reliable.

The distribution of C. albida along Atlantic North American coasts and its temperature response in culture resemble that of the northeastern American tropical-to-temperate species, Grinnellia americana and Lomentaria baileyana. They are common along the warm temperate shores, and penetrate far into cold temperate waters, where they reach their summer growth limits. Tropical records, however, are very rare and are mostly restricted to the tropical margins (Yarish et al., 1984).

\section{Cladophora hutchinsiae}

The rather narrow range of temperatures for optimal growth $\left(15^{\circ}-25^{\circ} \mathrm{C}\right)$ and the limited survival range $\left(5^{\circ}-30^{\circ} \mathrm{C}\right)$ were consistent with its restricted distribution in the eastern Atlantic and its absence from the American coast (Fig. 8). At any point along this coast, winter temperatures will be too low or summer temperatures too high, or both, for survival. In this respect $C$. hutchinsiae resembles a number of other species in the Mediterranean-Atlantic warm temperate group for which experimental data are available, viz. Saccorhiza polyschides (van den Hoek, 1982a); Halurus equisetifolius, Callophyllis lacinata and Hypoglossum woodwardii (Yarish et al., 1984) and Gracilaria bursa-pastoris (McLachlan \& Bird, 1984). 

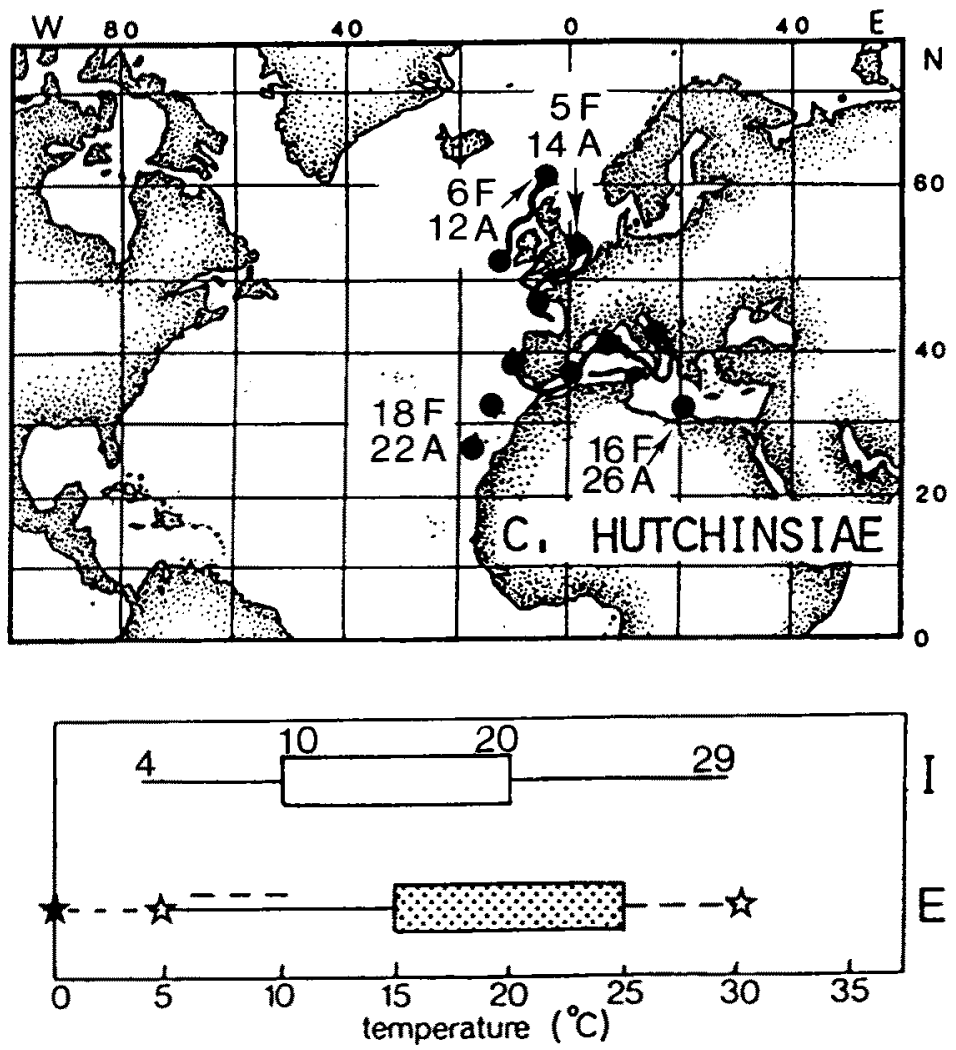

Fig. 8. Cladophora hutchinsiae (Mediterranean and East Atlantic warm temperate distribution). Additional distribution data for W. Scotland and Orkneys from Norton (pers. comm.); for Madeira and Salvagens from Levring (1974); for Libya from Nizamuddin et al. (1979). See text to Fig. 3 for explanation of symbols, equatorward southern boundary present

At its northern boundary in the Orkney Islands (T. Norton, pers. comm.) near the $6^{\circ} \mathrm{C}$ February and $12^{\circ} \mathrm{C}$ August isotherms, $C$. hutchinsiae must survive at least $5^{\circ} \mathrm{C}$. The lethal temperature lies between $0^{\circ}$ and $5^{\circ} \mathrm{C}$ in short days and dim light but above $5^{\circ} \mathrm{C}$ in long days and brighter light. Winter temperatures are probably not lethal in most years, and it is probably only in spring when occasional cold periods coincide with longer days and bright light that low temperatures could cause significant chilling damage. The summer temperature of $10^{\circ} \mathrm{C}$, which has to support "sufficient" growth, is at the lower end of the experimental $5^{\circ} \mathrm{C}$ interval over which growth exceeded $20 \%$ of its maximal rate (between $10^{\circ}$ and $15^{\circ} \mathrm{C}$ ). So a summer growth limit is acting not far south of a potential lethal limit at this northern boundary. In the North Sea $\left(5^{\circ} \mathrm{C}\right.$ February, $14^{\circ} \mathrm{C}$ August) the boundary is probably set by low lethal winter temperatures.

The southern boundary in the Mediterranean $\left(16^{\circ} \mathrm{C}\right.$ February, $25^{\circ} \mathrm{C}$ August) is clearly set by a summer lethal temperature, as the summer temperature of $29^{\circ} \mathrm{C}$ lies in the experimental interval where the lethal limit was reached $\left(25^{\circ}-30^{\circ} \mathrm{C}\right)$, whereas winter temperatures were close to the optimum (Fig. 2) and well within the range for 
"sufficient" growth (Fig. 8). At the southern boundary in the Canary Islands the summer temperatures are below the lethal limit and so the species could be expected to occur somewhat further south along the African coasts.

\section{CONCLUSIONS}

For five of the six investigated species (Cladophora coelothrix, C. vagabunda, C. dalmatica, $C$. rupestris and $C$. hutchinsiae), experimentally determined temperature limits to growth and survival were consistent with summer and/or winter temperatures at the geographic boundaries and conclusions could be drawn about the phase in the annual temperature regime at each boundary which would prevent the species from expanding beyond its present latitudinal range, i.e. which sets the geographic boundary (Figs $3,4,5,6,8$ ).

For C. albida (Fig. 7) on the other hand, the experimentally determined upper limits for growth and survival were much higher than those expected on the basis of distribution indicating that the species could be expected in the tropics. Here adverse nutrient conditions might restrict the distribution. The high growth rates of $C$. albida (especially of the Connecticut-strain) in the nutrient-rich culture media suggest a requirement for eutrophic conditions, whereas most of the tropical Caribbean coasts are characterised by oligotrophic conditions. This will be further investigated.

Finally, it is interesting that strains of six different Cladophora species from one collecting site (Roscoff, Brittany/France) have such divergent temperature ranges for growth and survival, which can be largely explained in relation to differences in geographic distribution.

Acknowledgements. We wish to thank Mrs K. Cameron and Mrs K. Stuit for typing the manuscript. The investigation was supported by the Foundation for Fundamental Biological Research (BION), which is subsidized by the Netherlands Organisation for the Advancement of Pure Research (ZWO). Professor C. Yarish collected the Connecticut strain of $C$. albida. The authors are indebted to the Director and Staff for their hospitality and working facilities at the "Station de Biologie Marine et d'Océanographie" at Roscoff (Brittany, France).

\section{LITERATURE CITED}

Gayral, P., 1958. Algues de la côte atlantique marocaine. La nature au Maroc II. Soc. Sci. Nat. Maroc, $523 \mathrm{pp}$.

Hamel, G., 1924. Quelques Cladophora des côtes françaises. - Revue algol, 1, 458-461.

Hoek, C. van den, 1963. Revision of the European species of Cladophora. Brill, Leiden, $248 \mathrm{pp}$. (Reprint Koeltz, Koenigstein, 1976).

Hoek, C. van den, 1979. The phytogeography of Cladophora (Chlorophyceae) in the northern Atlantic Ocean, in comparison to that of other benthic algal species. - Helgoländer Meeresunters. 32, 374-393.

Hoek, C. van den, 1982a. The distribution of benthic marine algae in relation to the temperature regulation of their life histories. - Biol. J. Linn. Soc. 18, 81-144.

Hoek, C. van den, 1982b. A taxonomic revision of the American species of Cladophora (Chlorophyceae) in the North Atlantic Ocean and their geographic distribution. North Holland Publ. Comp., Amsterdam, 236 pp. (Ver. K. Akad. Wet. Afd. Nat., R. 2, D 78.)

Hoek, C. van den, 1982c. Phytogeographic distribution groups of benthic marine algae in the North Atlantic Ocean. - Helgoländer Meeresunters. 35, 153-214.

Hoek, C. van den \& Womersley, H. B. S., 1984. Genus Cladophora Kützing 1853. In: The marine 
benthic flora of Southern Australia. P. I. Ed. by H. B. S. Womersley. D. J. Woolman, Government Printer, South Australia, 185-213.

Humm, H. J., 1979. The marine algae of Virginia. Univ. Press of Virginia, Charlottesville, 263 pp.

Hutchins, L. W., 1947. The bases for temperature zonation in geographical distribution. - Ecol. Monogr. 17, 325-335.

Levring, $T$, 1974. The marine algae of the Archipelago of Madeira. - Bolm Mus. munic. Funchal 28, 5-111.

McLachlan, J. \& Bird, C. J., 1984. Geographical and experimental assessment of the distribution of species of Gracilaria Grev. (Rhodophyta: Gigartinales) in relation to temperature. - Helgoländer Meeresunters. 38, 319-334.

Nizamuddin, M., West, J. A. \& Meñez, E. G., 1979. A list of algae from Libya. - Botanica mar. 22, $465-676$.

Orris, P. \& Taylor, J. E., 1973. A floristic and ecological survey. The benthic algae of Rehoboth Bay, Delaware. - Botanica mar. 16, 180-192.

Rueness, J., 1977. Norsk algeflora. Universitetsforlaget, Oslo, 266 pp.

Searles, R. B., 1984. Seaweed biogeography of the Mid-Atlantic coast of the United-States. Helgoländer Meeresunters. 38, 259-271.

Sourie, R., 1954. Contribution à l'étude écologique des côtes rocheuses du Sénegal. - Mém. Inst. fr. Afr. noire $38,1-342$.

South, G. R. \& Hooper, R. G., 1980. A catalogue and atlas of the benthic marine algae of the Island of Newfoundland. - Mem. Univ. Newfoundland Occ. Pap. Biol. 3, 1-136.

Sverdrup, H. V., Johnson, M. W. \& Fleming, R. H., 1942. The oceans. Prentice Hall, Englewood Cliffs, NJ, $1060 \mathrm{pp}$.

Yarish, C., Breeman, A. M. \& Hoek, C. van den, 1984. Temperature, light, and photoperiodic responses of some northeast American and west European endemic rhodophytes in relation to their geographic distribution. - Helgoländer Meeresunters. 38, 273-304. 